\title{
EFFECTS OF HANFORD REACTORS \\ ON COLUMBIA RIVER \\ AND ADJACENT LAND AREAS*
}

\author{
R. F. Foster
}

Associate Manager

Environmental \& Life Sciences

Battelle-Northwest the United States nor the United States Atomic Energy Commission, nor any of their employees, nor any of their contractors, subcontractors, or their employees, makes any warranty, express or implied, or assumes any legal liability or responsibility for the accuracy, completeness or usefulness of any information, apparatus, product or process disclosed, or represents that its use would not infringe privately owned rights.

*For presentation to the State of Washington Ecological Commission, Richland, Washington, December 15, 1970. 


\section{DISCLAIMER}

This report was prepared as an account of work sponsored by an agency of the United States Government. Neither the United States Government nor any agency Thereof, nor any of their employees, makes any warranty, express or implied, or assumes any legal liability or responsibility for the accuracy, completeness, or usefulness of any information, apparatus, product, or process disclosed, or represents that its use would not infringe privately owned rights. Reference herein to any specific commercial product, process, or service by trade name, trademark, manufacturer, or otherwise does not necessarily constitute or imply its endorsement, recommendation, or favoring by the United States Government or any agency thereof. The views and opinions of authors expressed herein do not necessarily state or reflect those of the United States Government or any agency thereof. 


\section{DISCLAIMER}

Portions of this document may be illegible in electronic image products. Images are produced from the best available original document. 


\section{Effects of Hanford Reactors \\ on Columbia River \\ and Adjacent Land Areas}

\section{The Hanford Site and Early Environmental Studies}

The Hanford site on the Columbia River (Figure 1) was selected as the location of the plutonium production plant after an intense nationwide search in 1943 by the Manhattan District of the Corps of Engineers. (The Atomic Energy Commission was not created until 1946 and did not take over the operation of the Hanford Plant until January 1, 1947.) In a very real sense, the bioenvironmental factors were dominant in the choice of the site and probably at no prior time in history was so much attention given to the potential impact of an industrial plant on the environment. This attention was in part a compensation for the complete absence of experience with any kind of installation that even remotely resembled what was to be built at Hanford. It also reflected the thoroughness with which the scientists associated with the project delved into all of thic technical facets.

The original mission of the Hanford plant was to produce an artificial element (plutonium) that was nonexistent prior to 1941. Without a Hanford plant, plutonium would exist only in milligram quantities and as a laboratory curiosity. Hanford was needed because it was believed that large amounts of plutonium could be fashioned into an atomic bomb that would swiftly bring an end to World War II. But, 
at the time that Hanford was chosen as the plutonium site, it was not known positively that the reactors which had been conceived as the means of creating plutonium from uranium would actually operate. Nor was it known positively whether the plutonium created in the reactors would actually work as an atomic bomb.

The basic process to be carried out at Hanford was to change uranium atoms into plutonium atoms and then to recover the plutonium in highly purified form by chemical engineering and metallurgical techniques. Thus the Hanford complex would require: (1) A fuel fabrication plant where pure uranium could be fashioned and jacketed into elements suitable for irradiation; (2) reactors where the uranium fuel elements could be irradiated and the plutonium produced; (3) chemical separation plants where the irradiated fuel could be processed and the plutonium recovered; and (4) waste storage and retention areas where highly radioactive chemical solutions could be kept isolated from the environment for very long periods of time.

According to theory, a chain reaction of fissioning uranium atoms could supply the flux of neutrons required to sreate plutonium atuils from some of the nonfissioning uranium atoms in the fuel elements. The chain reaction would, however, release very large quantities of heat that could best be removed by a water-cooled system. The chain reaction would also leave as debris highly radioactive fragments 
of the uranium atoms (fission products) that would eventually have to be stored as waste. Further, any material in the near vicinity of the chain reaction would be bombarded by stray neutrons and "neutron-activated" radioisotopes would be formed.

The Hanford site had the necessary attributes required to meet both the known and unexplored aspects of the plutonium production process. The Columbia River, with a flow second only to the Mississippi in the conterminous United states, was available for cooling water, and it could be relied upon to dilute to safe levels the kinds and quantities of radionuclides anticipated in the reactor coolant. The site was sparsely populated and agricultural development was minimal. Thus the government could acquire and maintain tight security on a relatively large control zone with the disruption of the home and farm sites of relatively few people. The waste storage areas could be located well inland from the river where there was a deep (200 to 300 feet) layer of dry soil above the water table. The atmosphere was relatively unstable most of the time and thus favorable for the rapid dispersal of airborne wastes. The semiarid climate favored year-round construction activities and plant operation, even though the summers were uncomfortably hot. Finally, an adequate block of electric power was available from the hydroelectric dams on the river to supply the heavy demands of the pumps and other process equipment. 
Consideration of the potential effects of the effluenls from the Hanford plants on the environment included at the outset:

- The impact of releases to the atmosphere on vegetation, native and domestic animals, and people-with special attention to the transfer of radioactive contaminants through vegetation to grazing animals.

- The impact of releases to the Columbia River on the valuable fishery resources of the river-especially salmon--and on people who used the river as a source of drinking water and recreation.

- The impact of releases to the ground on the quality of the groundwater.

The earliest studies that were undertaken to determine the possible impact of the plant effluent on Columbia River fish were actually begun at the University of Washington's. School of Fisheries. One reason for this was timing--the studies were begun in 1943, well over a year before the first reactor started operation. Another reason was security--intense secrecy applied to the Hanford Plant prior to the detonation of the first atomic bomb, and scientists using radiation or radioisotopes were purposely kept dissociated from the production site.

The first of the three original reactors built at Hanford began operation in September 1944, the second was 
started up later in 1944, and the third came on the line early in 1945. By mid 1945, studies on the toxicity of the reactor effluent to fish had begun in a special laboratory built for the purpose on the Hanford Reservation at the 100-F reactor site. This bioassay-type test showed that the concentrations of effluent that existed in the Columbia River downstream from the reactors were not harmful to trout and salmon.

Field work on the river specifically concerned with fish and other biota was begun in 1946. At the outset these studies were designed to explore the possibility that radionuclides released to the river with the reactor effluent were picked up by fish and other aquatic forms. With the recognition that the river biota were concentrating certain. radionuclides, more comprehensive bioenvironmental studies were begun. in 1947 that included benthic invertebrates as well as fish.

By 1949 the laboratory and river studies at Hanford had shown that the fisheries resources of the Columbia were not threatened by the plutonium plant, nor was there any health hazard to people who used the river and its fish. On the other hand, it was also rccognized that lie recuncentration of some radionuclides by aquatic forms was a very important mechanism by which radioactive waste could be returned to man. Further, it was recognized that the heat and process chemicals (sodium dichromate) added to 
the river with the reactor effluent could adversely affect aquatic life if the quantities were increased by perhaps an order of magnitude. Consequently, long-range plans for bioassay and bioenvironmental studies were formulated and a permanent aquatic biology laboratory was constructed in the 1-00-F Area in 1952.

The secrecy that shrouded the Hanford site from its conception through the first months of operation was lifted abruptly in August of 1945 with the detonation of the atomic bombs over Hiroshima and Nagasaki. From this time on, a concerted effort was made to inform other government agencies, interested scientists and the public of the kind of operations carried out at Hanford and of the studies underway to ascertain the impact of the plant effluents on the environment. Security restrictions were no longer applied to the bioenvironmental studies except for data that might disclose the capacity of the plant or certain technical details of the plutonium production process. Late in 1945 and during 1946 representatives of the U. S. Fish and Wildlife Service and the Oregon and Washington Departments of Fisheries and Game were invited to Hanford to observe the site and review the studies underway that involved the Columbia River.

In 1949 the AEC set up the Columbia River Advisory Group (CRAG) to review the Columbia River program and its result's and to provide advice on program direction and waste disposal practices. The members of CRAG were senior officers in the Washington Pollution Control Commission, 
the Washington State Department of Health, the Oregon State Sanitary Authority, and the Portland office of the U. S. Public Health Service. These men were provided with security clearance so that no pertinent information was withheld. CRAG met at irregular intervals over a span of about 15 years.

During the early 1950's much attention was focused" on the tremendous potential for electrical power production from controlled chain reactions, and in 1955 the First International Conference on the Peaceful Uses of Atomic. Energy was held in Geneva, Switzerland, under the auspices of the United Nations. This conference provided the first opportunity to describe the bioenvironmental studies of the Columbia to an international audience, and this was done in three papers. Second and third "Geneva" conferences were held in 1958 and 1964, and new data were reported at each of these meetings.

With the reporting of investigations through 1959, both the scientitic community and the general public acquired some appreciation of the existence of radionuclides in the natural environment, and broad interest in extending the scope of the bioenvironmental studies was generated. A part of this interest was in the use of the radioactively tagged Columbia River water as a tool for studying the dynamics of the physical, chemical and biological systems of the river and adjacent Pacific Ocean, and a part of the interest 
was focused on the fate of the nuclides as a practical demonstration of the behavior of radioactive wastes in river, estuarine and marine environments. In order to carry out the extended program, the AEC placed several new contracts with groups that were uniquely equipped to undertake the work and that had a special interest in doing it. These included the Bureau of Commercial Fisheries, the Department of Oceanography of the University of Washington, the Department of Oceanography of Oregon State University, and the U. S. Geological Survey. Some of the efforts of the University of Washington Laboratory of Radiation Ecology (Applied Fisheries) and of the Hanford laboratories were also redirected so as to contribute even more fully to the overall program. A program coordinating organization, called the Working Committee for Columbia River Studies, was formed in 1962 to help unify the efforts. The Hanford Reactors as a Source of Radionuclides

Although no water-cooled reactor had ever operated before tlie startüp of the 100-B unit at Hanford in September of 1944, the presence of a complex mixture of radionuclides in the effluent water was predicted on the basis of the design. This prediction prompted the studies on the effects of radiation on fish that were initiated at the Universily of Washington in 1943, and it also prompted the inclusion of special structures (Figure 2) and precautions to assure that excessive amounts of the radioactive contaminants were not 
released to the columbia River. The structures included large concrete retention basins where the effluent could be held for a few hours before release. Even such brief retention allowed significant radioactive decay of many of the very short-lived nuclides.

The major source of the radionuclides in the effluent was correctly predicted to be from the neutron activation of elements dissolved in the cooling water or present on the surfaces of the reactor piping and fuel elements. The original Hanford reactors were designed so that the cylin-, drical fuel pieces of uranium laid as long horizontal columns inside of large aluminum tubes. When the reactors are operating, the process of atomic fission creates much heat within the fuel pieces that must be carried away. In order to keep the temperature at desired levels, cooling water is pumped through the aluminum tubes and passes through a space between the fuel elements and the tube wall. The surface of the fuel elements is an aluminum (or in recent years a zircontum) facket that prevents the uranium metal from contacting the cooling water.

There are nine reactors located along the banks of the Columbia River, bui only two of them now remain in operation--the other seven have been shut down because the present demand for plutonium is no longer great enough to require their output. One of the two reactors remaining in operation produces both plutonium and steam for the generation of electricity. This dual-purpose reactor, called the 
$\mathrm{N}$-reactor, more closely resembles contemporary power generating reactors because its primary cooling system is a closed loop that is isolated from the heat sink--the Columbia River. The other operating reactor $(100-K E)$ is a plutonium-only unit and, like the seven shutdown reactors, is cooled directly with Columbia River water rather than by a recirculating loop. The effluent of $\mathrm{KE}-$ reactor (and its shutdown sister reactors when they were in operation) contains a great variety of nuclides because of the neutron activation of natural constituents present in the river water, some chemicals added to the coolant, and corrosion products flushed from the surface of the fuel elements and fuel channels. The effluent also contains relatively small amounts of fission products that result from the fissioning of uranium present naturally in the river water and, occasionally, from a failure of the aluminum or zirconium jacket of a fuel element. Thus, the effluent from Hanford reactors contains virtually every kind of radionuclide Iikely to be encountered in the liquid wastes of contemporary light water power reactors, but in quantities substantially greater than is characteristic of units with recirculating primary loops. Figure 3, which was drawn several years ago when all of the direct-cooled reactors were operating, cmphasizes the great difference in radionuclide discharge between the plutonium production reactors and reactors designed for the generation of electricity. It should also be emphasized that the discharge 
today is much less than shown in Figure 3 because only one of the direct-cooled reactors remains in operation.

When the desired amount of plutonium has built up in the fuel elements, they are discharged from the reactors and transported to the chemical separations plants located on a plateau in the center of the reservation (Figure 4). Here the elements are dissolved and the plutonium is recovered by an organic solvent process, (Only the Purex. plant is now in operation because it can easily handle the output from the two reactors remaining in operation.) Dissolution of the fuel elements allows gaseous and quasigaseous fission products to enter the process system. This includes noble gasses, iodine, tritium and ruthenium. Elaborate clean-up systems minimize the amounts of these airborne radionuclides that reach the atmosphere.

None of the liquid waste from the chemical separations plants goes directly back to the columbia River. The highly radioactive liquids are stored in underground tanks and eventually evaporated to a nonfluid salt cake. Less radioactive liquids. (mostly the cleaned-up liquids from the waste concentration processes) are released into the soil which effectively retains most of the nuclides more than 200 feet above the groundwater. The quantities of radionuclides that eventually reach the columbia River via the groundwater are negligible.

Very soon after the radionuclides enter the river with the reactor effluent, major portions of most of them 
become adsorbed on suspended sediments or taken up by the phytoplankton. The radioisotopes of biologically important elements enter the food web and are ultimately deposited in fish and other organisms that may be used as food by man. However, the fraction of the total inventory of radionuclides that is retained in aquatic animals is quite small. 'Further, a major part of the radioactivity is from very short-lived nuclides, and it diminishes appreciably with time and distance downstream.

Deposition of the suspended sediments is of paramount importance in the depletion of the nuclides from the river water, and MCNary Reservoir--the first impoundment downstream from Hanford--is an effective trap. On the basis of measurements of the quantities of radionuclides transported by the river at Pasco and then downstream at Vancouver, the depletion in this 220 mile stretch of the Columbia varies from a minimum of about 10 percent for two common nuclides to as much as 80 percent for several others during most of the year. A part of the longer-lived radioactive materials deposited with the sediments is resuspended by the spring freshet and again transported by the river.

Some of the data on the flux of radioactive material in the columbia has been generated by research programs concerned with aquatic biology and with the sediments. A major portion of it has also been generated by the Environmental Surveillance Program, however. This surveillance 
program is directed primarily toward the evaluation of the radiation dose to man that results from the release of the radionuclides into the environment. In order to properly evaluate the dose, the combined contributions of all of the Hanford facilities and all of the potential pathways of exposure have to be taken into account. Figure 5 shows several of these pathways. The Columbia River is used as a water supply for the cities of Richland, Kennewick and Pasco. It is also used for irrigation on small farms that include dairy cows, beef cattle, fruit, hay, and family gardens. Further, the river is the center of recreation for the local area and provides fishing, waterfowl hunting, boating, water skiing, and picnicking. The many small farms and gardens of the area also provide the typical exposed surfaces of pasture grass and leafy vegetables upon which airborne materials can settle. Thus, of the many conceivable exposure pathways that could be associated with nuclear power reactors, virtually all of them are available and have heen studied in the environs of the Hanford Plant. Marine pathways are not close at hand, but the Columbia River does empty into the Pacific Ocean some 380 miles downstream from the reactors, and residual amounts of the waterborne nuclides are available to shellfish and other food chains of the ocean along the adjacent coasts of oregon and Washington.

About 90,000 people live near the Hanford project-either in the 'l'ri-Cities or in the agricultural area near by. 
Because of the variety of foods and beverages available to these people, the different amounts of radionuclides they contain, and because of different home sites and recreational preferences, no two individuals have precisely the same intake of radionuclides or encounter quite the same radiation exposure. The residents of Richland take in more radionuclides with their drinking water than do the residents or Pasco or Kennewick, while the inhabitants of the agricultural areas, who derive their water from wells, receive virtually no exposure from their drinking water.

Although fishing is a popular recreation in the TriCity area, only a small fraction of the total population actually catch and eat fish that inhabit the Columbia River downstream from the reactors. Assessment of the intake of nuclides with the consumption of local fish is especially complex because the quantity of fish consumed by individuals ranges from zero (many fishermen do not like to eat fish) to several meals a week at times when fishing is especially good. So many combinations of the various sources of exposure are possible, that the general population in the vicinity of the Hanford plants cannot be considered to be "homogeneous" in respect to some "average" dose received as a result of plant operations. Most individuals acquire radionuclides that are transported by the Columbia River only via the drinking water supplies of the cities of Richland, Pasco, and Kennewick, but a very few individuals acyuire much greater quantities of ${ }^{32} \mathrm{P}$ and ${ }^{65} \mathrm{Zn}$ from local fish and waterfowl. 
We are deeply indebted to $\mathrm{Mr}$. John Biggs and his former staff in the state Game Department for the assistance they have provided in determining the kinds and amounts of fish and game harvested and eaten by local sportsmen. It is the results of the surveys made largely by the Game Department personnel that we use to estimate radionuclide intake from these sources.

Because of the wide differences in peoples' habits and thus their exposure to environmental sources of radioactivity, the use of some "average" exposure for any significant number of people fiails to call attention to the much larger exposure received by the very few. On the other hand, the magnitude of exposure received by the very few certainly should not be viewed as characteristic of the vast majority. In order to satisfy both conditions, two separate dose estimates are made; one is for the average resident of Richland; the other is for a hypothetical individual whose place of residence and personal habits result in the highest exposure that can rationally be postulated.

Figure 6 shows the final result of the dose computations for the "maximum individual" for the year 1968. (The evaluation for 1969 has been completed, but the report is not yet off the press. The dose estimates for 1968 when four of the reactors were operating are below those calculated for 1965 when all of the reactors were operating, but greater than for 1969 and 1970 when fewcr reaclors remained 
in operation.) The "critical organs" of interest are the bone, the whole body, the gastrointestinal tract, and the infant thyroid. For each of these critical organs the calculated annual dose is shown as a percent of the limit for individual members of the public. Also shown for each organ are the contributions to this dose contributed by specific radionuclides (or external gamma radiation) and by specific kinds of foods or beverages.

The dose to the bone for this year was estimated at about 250 mrem, or 17 percent of the limit. Most of this is postulated to have resulted from ingestion of radiophosphorus that had accumulated in local fish which were caught by sportsmen. The percent of limit calculated for the dose to other organs was less than in the case of the bone, and nuclides other than radiophosphorus were relatively more important.

Figure 7 shows data similar to that of Figure 6 but for the average Richland resident. The calculations for the average resident differ from those for the maximum individual in two important aspects. First, the dose limits are only one-third as great because populations of people are involved and second, average rather than dose-maximizing dietary habits are used.

The calculated bone dose for the average Richland resident was 13 mrem or about three percent of the limit. As in the case of the maximum 1ndividual, radiophosphorus was the dominant nuclide, but the averáge resident eats 
hardly any fish caught from the river, so drinking water and produce from irrigated land become the most significant sources.

In line with Federal Radiation Council recommendations, the most limiting case for ingestion of radioiodine is the infant thyroid. This is because of the relatively small size of the gland, in which iodine ingested with water and milk accumulates. These considerations lead to dose estimate of about 40 mrem to the average infant thyroid or about eight percent of the limit.

It may be noted from Figures 6 and 7 that the dominant environmental sources of radiation exposure are associated with the Columbia River (rather than the atmosphere) and with local foods and beverages. In order to determine the quantities of these items that are consumed, several thousands of local adults and children have been questioned about their food habits. The fish and waterfowl surveys carried out by the State Game Department and mentioned earlier are a part of this overall study.

The conclusion that can be drawn from this work is that the calculated doses for the people who live in the vicinity of the large Hanford nuclear complex have always been well within the limits recommendea by the Federal Radiation Council, the National Council on Radiation Protection and Measurements and other authoritative groups. These calculated doses are based on excellent field data, on techniques that sum exposure 
from the multiple sources, and on assumptions that tend to overstate the actual dose received. The releases of radioactive materials from the Hanford plants to the atmosphere and to the Columbia River have been orders of magnitude greater than those that are associated with the normal operation of power reactors of contemporary design. Consequently, the Hanford experience provides a substantial block of evi"dence that major nuclear installations can be operated for extended periods of time at very small fractions of the dose limits now applicable to members of the general public. Radiation Effects on Fish and Waterfowl

In addition to the potential radiation dose to man from the Hanford effluents, we must also take into consideration the potential radiation effects on fish and wildlife. Possible effects of radiation on these forms were uppermost in our minds when the studies on the effects of $x$-rays on fish were begun at the University of Washington in 1943, when the aquatic laboratory at the $100-\mathrm{F}$ reactor was established in 1945, and when field observations on Columbia River fish and waterfowl were started a few years later.

The laboratory work in which actual reactor effluent was supplied continuously to troughs of fish soon showed that no adverse effect could be seen unless the concentration of the effluent was several times greater than existed in the Columbia River. It was also shown that adverse effects that eventually occurred in the high concentrations after weeks of exposure resulted not from radiation but from toxicity 
of a form of chromium added to the cooling water as an aid in the prevention of corrosion.

The research work at Hanford, at the University of Washington, and at many other places all show that natural populations of fish and wildlife are not at risk from the levels of radiation in the environment that have to be maintained in the interest of man. There are several reasons for this. One is that fish and the lower forms of life are more resistant to radiation than is man, another is that the dose limits for man contain safety factors that are more stringent than are ordinarily applied to nonhuman species, and $a$ third is that any genetic defects are soon eliminated by natural selection.

Fish eggs have been shown to be the life stage most sensitive to radiation, and estimates have been made of the dose received by salmon. eggs deposited in the river below the Hanford reactors. These dose estimates can be compared with radiation used in studies made at the University of Washington where chinook salmon eggs and fry were exposed chronically to radiocobalt. The radiation dose used initially at the University of Washington was about 40 times the maximum dose calculated for the eggs and fry in the columbia River, and was about 1,000 times that of the natural background. Although the number of abnormal fish.was increased by the irradiation, the size and number of fingerlings was not significantly affected. These young fish were then liberated and left to compete with natural stocks 
of fish in the ocean. When they returned as adults they were compared with similar but nonirradiated fish. Rather than showing any adverse effect, the irradiated stock actually returned in greater numbers and produced a greater total of viable eggs than the nonirradiated stock.

I mentioned above that Columbia River fish accumulate radiophosphorus, radiozinc and a few other nuclides from the river water and from food organisms. In order to determine the amounts of these radionuclides that can be deposited in fish before measurable radiation damage occurs, massive quantities of the key nuclides were fed to young trout for extended periods of time. Some of the results are shown in Figure 8. It turned out that radiophosphorus is potentially more damaging to the fish than radiostrontium and radiozinc because of its effect on blood-forming tissues. However, no ill effects were seen in trout that contained 100 times more radiophosphorus than was found in wild fish of the Columbia River. Damage did occur when the burden of radiophosphorus was about 1,000 times that found in river fish. Such high levels are entirely out of the question when the fish are to be used as food by people. In the case of radiozinc, concentrations in the fish 10,000 times greater than in river fish produced no detrimental effects.

Besides the stocks of fish, we have also had a keen interest in the waterfowl, especially the Western Canada Goose, that nest. on the islands in Lhe Columbia River. Because of their chosen nesting sites and the availability 
of radionuclides in aquatic foods produced by the Columbia River the local waterfowl receive a greater exposure to radiation than other warm-blooded animals. The success of the nesting of the geese has, therefore, been followed since 1950. Some of the data is summarized in Figure 9. During this 20 year period, hydroelectric development of the columbia and Snake Rivers has gradually inundated the natural. nesting sites of the geese to the extent that the Hanford population now occupies the only major remaining habitat on the columbia. Maintenance of local Canada goose populations in the columbia and Snake River systems depends critically on nesting habitat, and this is almost exclusively dependent on islands. The inundation of the original nesting sites and other factors affecting nesting success have been so great that one would not expect to see any subtle effect from radiation. Also, substantial evidence was already at hand that argued against any environmental damage from the Hanford plants. Nevertheless, continued long-term observations were made to confirm the initial interpretations. Infertile eggs were of prime interest because they represented the measure of reproductive performance of adults reared and resident in the environs of Hanford. Average fertility of adults with such a history has been about 97 percent which is equal to or better than that reported from areas in which there has been no exposure to artificial environmental radiation. Fertility ranged from 95 to 99 percent during the study, with no pattern with respect to time or location. Thus, the data indicate that 
neither the number of reactors operating during any one time nor the proximity of the geese breeding ground to the reactors had a measurable effect upon the geese.

Secondary factors perturbing the goose populations were studied as well. These are predation (by coyotes, people and magpies, in that order) and destruction or desertion of nests due to natural flooding and water management techniques. The predation factor is reflected in declining numbers of nests for the area under study. Banding as well as nesting studies have been carried out, for both radioecological purposes and as a contribution to wildlife management practice. These population and banding studies have been carried out in close cooperation with both the state Game Department and the Bureau of Sportfish and Wildlife. The Hanford Reactors as a Source of Heat

The possible effect of waste heat from thermal power stations on the aquatic environment is one of the most intensely discussed environmental topics of the day. This problem has by no means been neglected in the overall bioenvironmental effects studies carried out at Hanford. The earlier bioassay tests undertaken in 1945 included temperature as one parameter of interest, and the data developed over the years in our laboratories and on the river near the effluent. nutfalls has contributed substantially to the available knowledge on the effects of heat on salmon and trout.

Before describing our work on bioeffects of heat, some 
background information on the nature of the reactor effluent and temperature trends of the Columbia River as a whole is pertinent. It was pointed out earlier that the radioactive characteristics of the Hanford effluents are not at all like those of thermal power stations. The temperature characteristics of the direct-cooled Hanford reactors are also quite different. Except for the N-reactor, the purpose of the heat transfer systems is only to keep the fuel elements from overheating, and not to produce steam to drive turbines. Consequently, most of the thermal energy added to the cooling water is still present at the time the effluent reaches the river. Also, because the cooling water from the plutoniumonly reactors is not involved with turbine efficiency, its temperature is much higher than that of the cooling water from electrical generating plants. It is, in fact, so hot that fish cannot survive in it until some dilution has occurred in the river.

Figure 10 gives an indication of the type of temperature pattern that occurs immediately bclow a poinl of discharge. Temperature increases on the order of $15^{\circ} \mathrm{C}$ occur only in partially diluted swirls of effluent immediately below the outfall, and they last only for a few seconds before dilution with the swift flow of the river brings the temperature down. Nevertheless, the potential for an acute effect on small fish is much greater in this mixing zone than in one from a thermal power station where the temperature of the undiluted cooling water is perhaps only $8^{\circ}$ to $10^{\circ} \mathrm{C}$ 
above that of the river.

The local impact of the Hanford reactors on the Columbia River temperature as a whole can perhaps best be described in terms of the rise that occurs between Priest Rapids, upstream from the Project, and Richland, which is below all of the facilities. Over the past five years, but including 1965 when most of the reactors were still in operation, the average temperature difference between these two points was in the range of $0.6^{\circ} \mathrm{C}$ to $1.5^{\circ} \mathrm{C}$. This difference includes heating or cooling by the sun and atmosphere as well as the effects of the Hanford reactos. These annual average temperatures are associated with average flow rates in the range of 115,000 to $134,000 \mathrm{cfs}$. The flow iates past Hanford are controlled by releases from Priest Rapids Dam, and this significantly affects the temperature that may be observed at any given time of day. It may be of interest to note that the annual average temperature increments just mentioned are equivalent to heat inputs (both natural and artificial) between Priest Rapids and Richland that are in the range of 9,000 to 23,000 megawatts .

Studies of the heat budget of the river indicate that a majority of the heat added by the reactors is dissipated to the atmosphere before the water reaches the confluence of the Snake River. At the oregon-Washington border, about 35 percent remains to be dissipated, but this varies from as ittle as five percent tc as much as 40 percent at different times of the year and unajer different weather conditions. 
of the heat added to the river in the Hanford region, only 20 percent or less is still present in the Columbia River in the vicinity of Bonneville Dam.

The comprehensive studies that have been made of the temperature regime of the columbia River system in connection with the Hanford plants have revealed a number of interesting facets that are associated with the impoundments behind the dams. A thorough analysis of the historic records indicates that the erection of low head reservoirs on the main stem of the Columbia River has not produced a significant change in. the annual average temperature of the river. The increase in the mean temperature at Rock Island-Rocky Reach between 1934 and the present time is only about $0.2^{\circ}$ to $0.4^{\circ} \mathrm{C}$, and this is largely associated with slightly warmer temperatures in the winter and possibly warmer atmospheric conditions. Peak summer temperatures are actually lower now than in the early 1940's (Figure 11). The most significant change that has occurred is a delay of about 30 days in the timing of the peak temperatures. This delay is associatcd with the hold up of the river water in Lake Roosevelt.

Figure 12 shows the early (1939-41) temperature pattern at the Bonneville Dam in relation to more recent years (1965-67). The delay in the arrival of the peak temperatures is evident here (as it was at Rock Island), and winter temperatures are also no longer quite so cold. At Bonneville, however, the summer temperatures are no cooler now than in the early years. Figure 13 shows the long-range temperature trends for both 
Rock Island and Bonneville. The annual mean and upper extrcme tempeidatures at Bonnevilie show a slight warming trend in relation to the Rock Island temperatures since 1960. This change is attributed to a combination of Hanford plant operations and heating during the hot summer months by the snake River. We now recognize that the historical data on water temperatures at Bonneville have not been truly representative of the bulk flow of the river as a whole because of the measurement location. Therefore, caution must be used in the application of these data.

The significant point that is apparent from the historical data is that peak temperatures in the Columbia River are not much different today than they were more than a quarter century ago when the records were first started. The peak temperature now occurs about a month later than in early years and this shift is most apparent in the upper river. The filling of the large reservoir behind John Day Dam has tended to smear out the seasonal shift in the lower river by increasing the opportunity of the water temperature to equilibrate with the atmosphere.

One can postulate that the heat added to the Columbia by the reactors might affect fish in a number of different ways and that the stock of fall chinook salmon that spawns in the Hanford reach may be especially vulnerable. A number of different kinds of studies have, therefore, been carried out on salmon and trout. 
Because the eggs of salmon are known to be particularly sensitive to elevated temperatures, some of the first tests were designed to see how much heat could be added to columbia River water without affecting the survival and development of the eggs. We concluded that if the eggs were spawned in temperatures greater than $15^{\circ} \mathrm{C}$ some loss should be expected. In most years this does not present a problem because most of the local chinook salmon spawn from mid-october through November when the temperature is rapidly declining from about $15^{\circ}$ to $10^{\circ} \mathrm{C}$. A few fish spawn as late as December when the water temperature may be as cold as $5^{\circ} \mathrm{C}--$ well below the optimum. The shift in the time of occurrence of peak temperatures in the river as a whole now presses heavily on the salmon that spawn earliest in October.

Incubation of the eggs and development of the young salmon occur from. late october through April when the Columbia River is sufficiently cold that heat additions of the magnitude of those added by the Hanford reactors cannot raise the temperature ahove the optimal rallye.

The seaward migration of young salmon past Hanford occurs in two waves: one during the spring at the time of the freshet, and the other late in the summer. Although river temperatures are within the optimum range when most of the fish move through, some concern has been expressed that a fraction of the migrants might be sivept directly into the hot, unmixed effluent as it jets out of the effluent pipe. This question has been investigated both in the 
laboratory and in the field.

The laboratory tests have sought to establish how much of a temperature "shock" the young fish can tolerate considering both the temperature of the water and the length of time that the fish are exposed. At first the reference point was the death of the test fish. Next we used a less severe reference point--the. "shock" which caused the fish to lose equilibrium. Recently we have been using a more subtile measurement, the ability of the test fish to escape a large predator fish in comparison with the escape ability of controls, all held in the same tank. The laboratory results now need to be coupled with estimates of the kinds of temperature shocks that could actually occur in the river. At this time we recognize that very, very few of the downstream migrants could find themselves in an untolerable zone at the point of discharge.

The field tests in the effluent plumes in the river have been of two types. In one case, a floating trap provided by the Fish and Wildlife Service was "fished" directly in one of the plumes with the thought that young salmon affected by the warm water could be caught and examined. Only a very few young salmon were captured and none of these showed any adverse effects from the effluent. The other field tests involved holding small fish in small cages (or live-boxes) and then drifting the cages directly through the effluent plumes. Drifts were carried out in the spring and 
again in the late summer and early fall. In the spring series the natural temperature of the river was low, and the temperature shock of the plume was not sufficient to cause. mortality. Even in the late summer and early fall when ambient river temperatures were relatively high, mortalities were not significant. Only in one test, carried out in 1969 at a very low flow $(40,000 \mathrm{cfs})$, was significant mortality recorded. On this occasion the test fish were exposed to a temperature rise of $22^{\circ} \mathrm{C}$ in the mixing zone. Some drift tests have been made close to the shoreline where little springs of hot water seep out through the gravel. These springs are fed by effluent disposal trenches higher up on the bank. Many of the caged fish have died when forced to remain in these local seepage zones, but we doubt that young salmon that are free to swim about in the river ever enter these areas of high temperature and low current velocity. When adult salmon return from the sea, it is essential that they reach their ancestoral spawning grounds without significant delay, and there has been some ispeculation that thermal discharges might block their migration. In order to determine if any significant delay occurs in the Hanford reach, a cooperative field study was undertaken by us and the U.S. Bureau of Commercial Fisheries. Small battery-powered tags that emit a sound were attached to salmon and steelhead trout and then the movements of the fish were followed by men in boats equipped with hydrophones. This equipment was 
developed by BCF. Our crews recorded locations or migration paths of 70 tagged fish in August and September of 1967 and 368 fish between May and October 1968. For the most part, the tagged fish were located near shore on the side of the river away from the reactors. We are not at all sure that the reactors had anything to do with the fish favoring the left bank, because this basic pattern also existed for many miles both above and below the reactors. of more significance was the observation that the speed of migration did not appear to be influenced by the reactors and thus there was no evidence of any blockage.

The size of the population of chinook salmon that spawns in the Hanford reach has been of special interest because one can postulate that any significant deleterious effect of the effluents will cause a decline in the local stock. An effect could be caused by radiation, toxic chemicals, heat, or a combination of them, and it could be directly on the fish or on the food organisms that support the fish. With this in mind an annual census of the number of nests that could be observed was started in 1947. As shown in Figure 14, spawning occurs both upstream and downstream of the reactors. The census data from 1947 through 1969 are shown in Figure 15. The marked increase in the number of nests between 1965 and 1969 is not considered to. be related to the shutdown of reactors during that period (the adults are actually the results of spawning four years earlier) but rather due to other environmental factors and 
quite likely the displacement of spawners from other sections of the Columbia River when new dams inundated their spawning grounds. One factor is self-evident, however. Any adverse effect that the Hanford effluents may have had on this population of salmon is so small that it is completely overwhelmed by other environmental factors that control the abundance of the fish.

For completeness I should mention our work on fish diseases and especially columnaris. In general, increased water temperatures favor most fish diseases and columnaris is no exception. Studies on columnaris have been carried out both in our laboratory and in the river since 1959. There is no question that the infection of fish with columnaris becomes evident when the water temperatures rise above $10^{\circ} \mathrm{C}$ and declines when the temperature decreases. However, the focal points for infection of fish in the Columbia River are not the artificial heat additions, but rather the fish ladders. at the dams where the salmon are brought into close association with scrap fish that are resident in' the ladders. Conclusion

In conclusion I would like to emphasize again that the effluents from the Hanford plants are not typical of those from reactors designed solely fop the production of steam for electricity. Rather they have a greater potential for causing effects because of their unusually large concentrations of radionuclides and their unusually high temperatures. Nevertheless, comprehensive studies over more than 25 years 
have shown that the radiation doses received by the public have been well within the guidelines and that no discernible radiation or thermal effects have occurred to the valuable populations of fish and wildlife. 


\section{HANFORD PROCESS FLOW CHART}

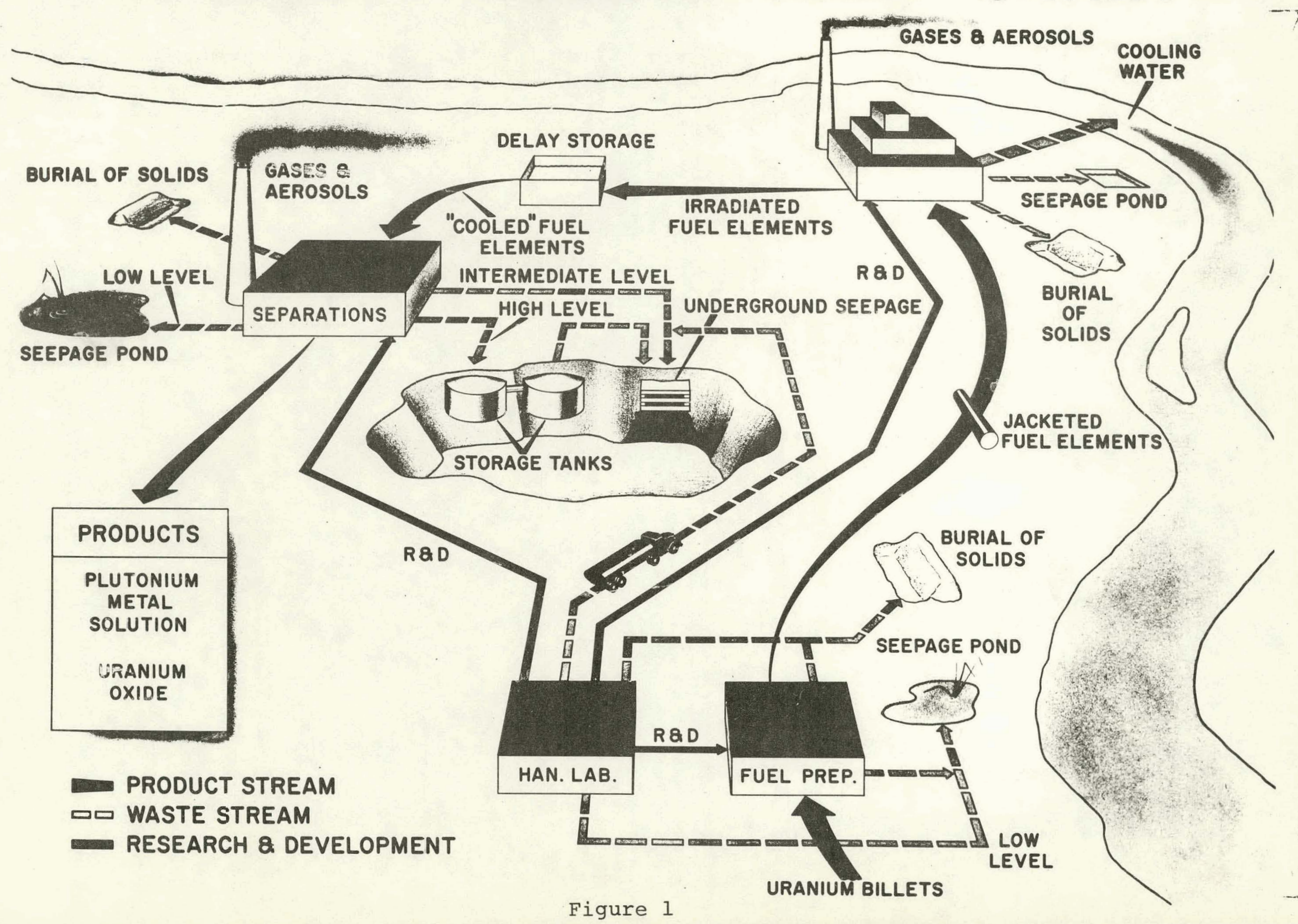




\section{WATER FLOW \\ THROUGH A TYPICAL REACTOR AREA}

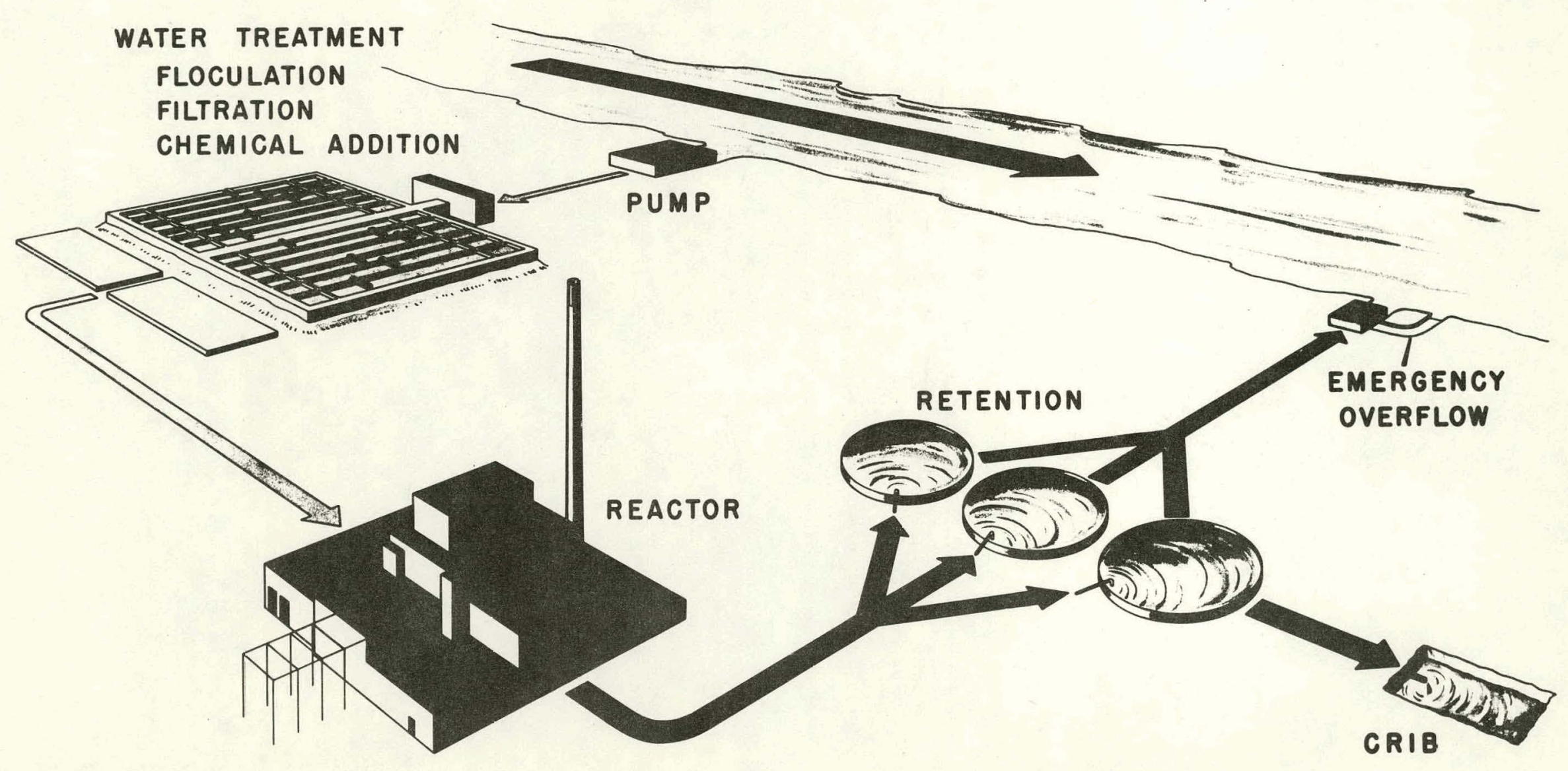

Figure 2 


\section{LOW LEVEL WASTES ADDED TO STREAMS}

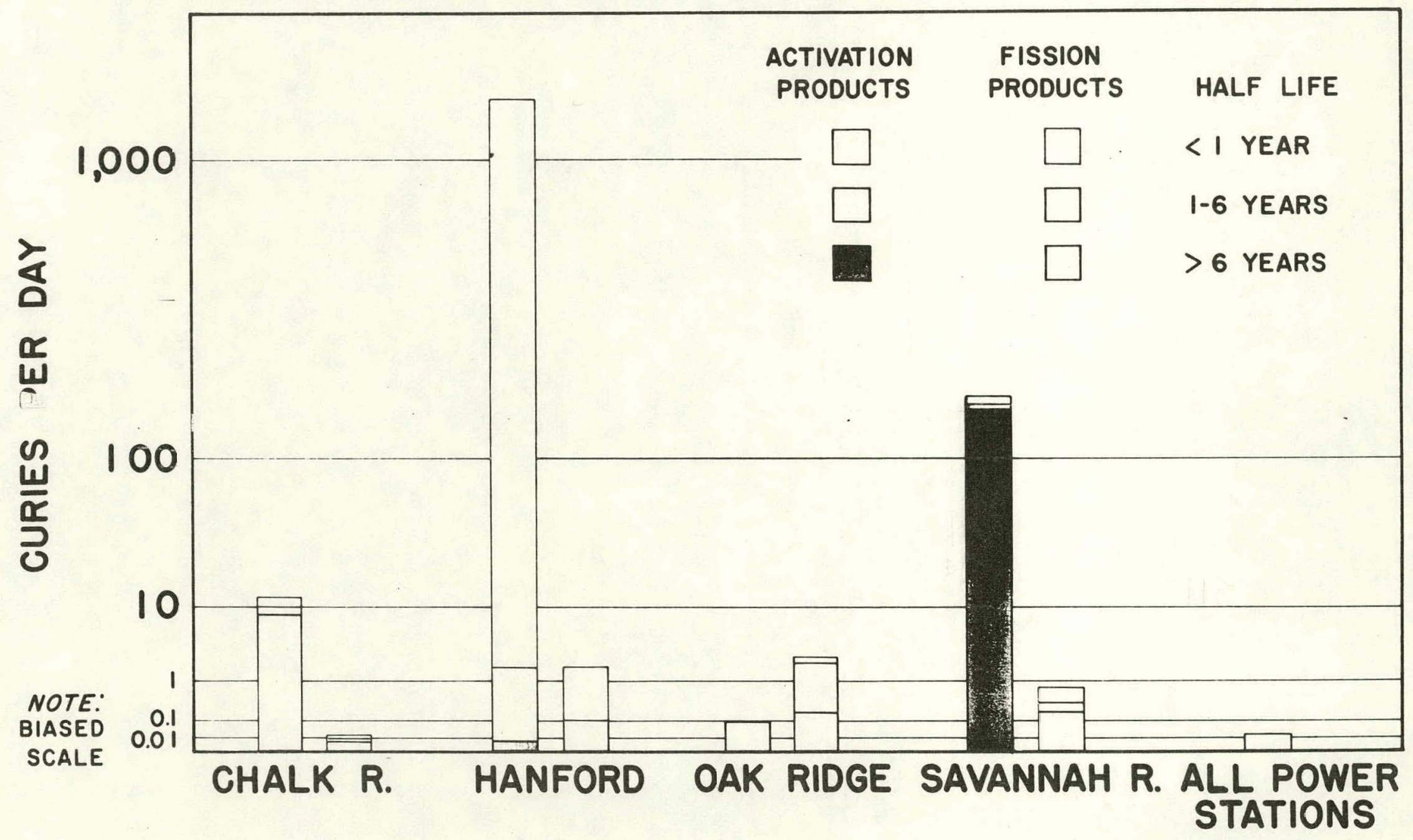




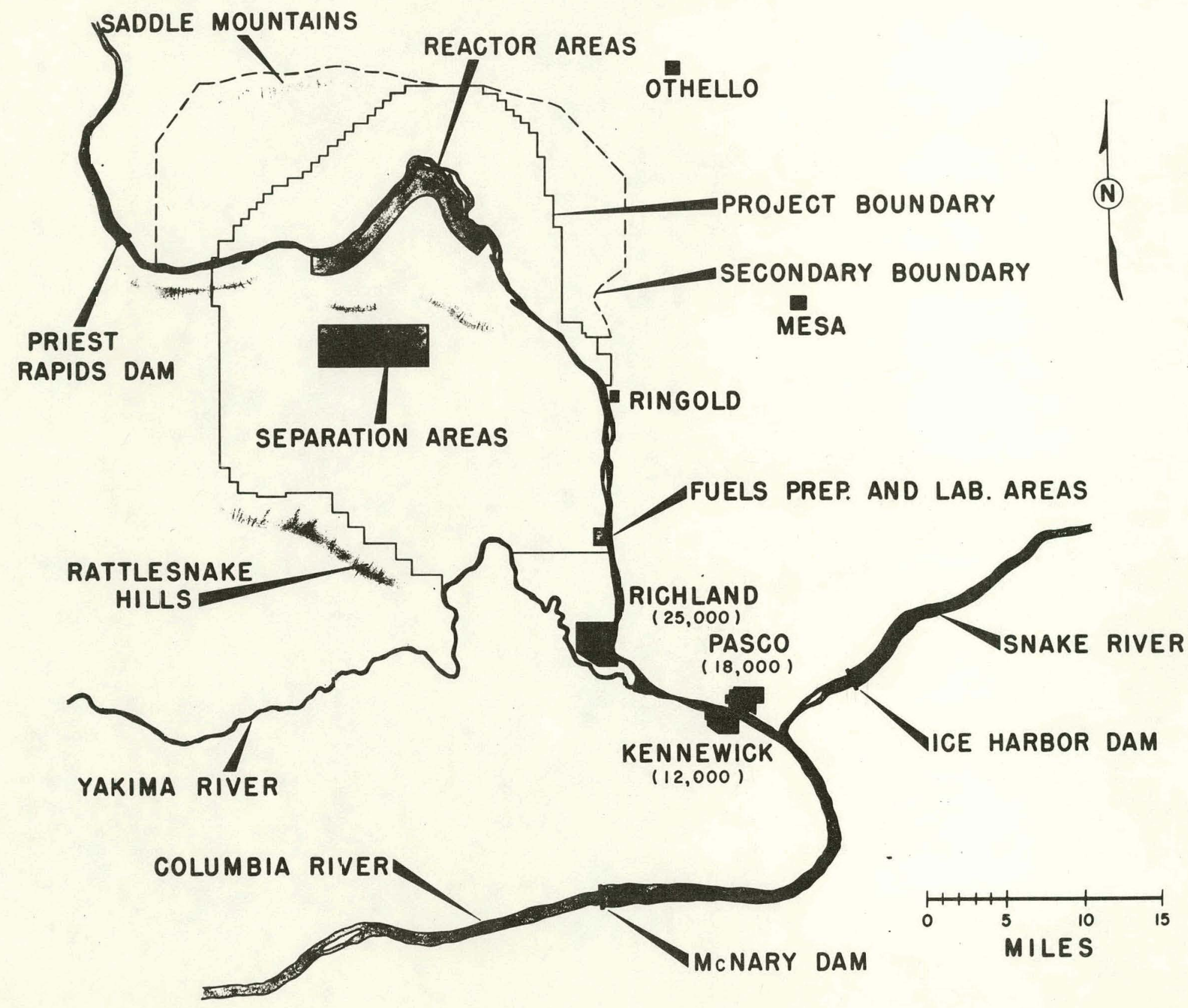

Figure 4 


\section{EXPOSURE PATHWAYS FROM REACTOR EFFLUENT}

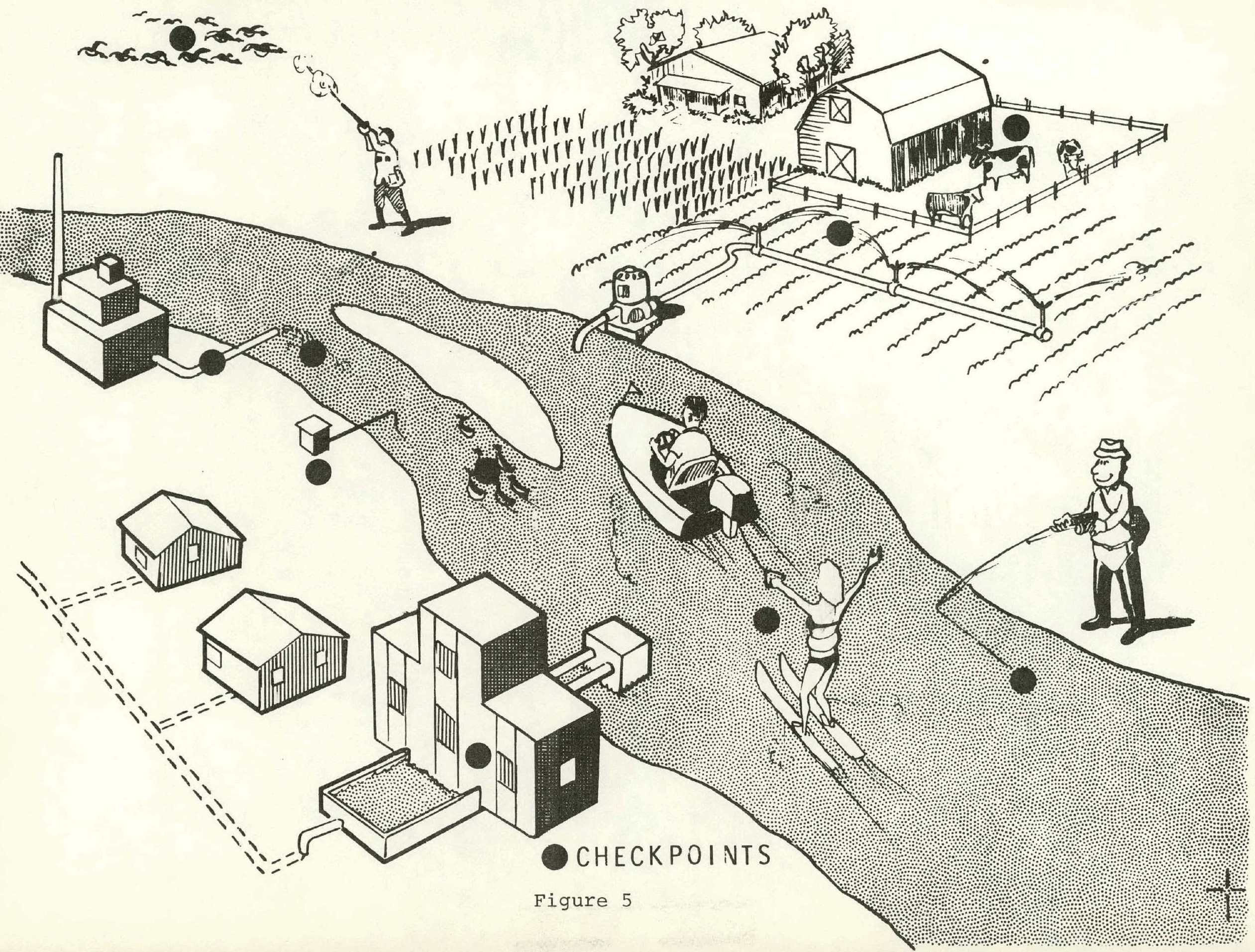




\section{ESTIMATED DOSES TO THE MAXIMUM INDIVIDUAL-1968}
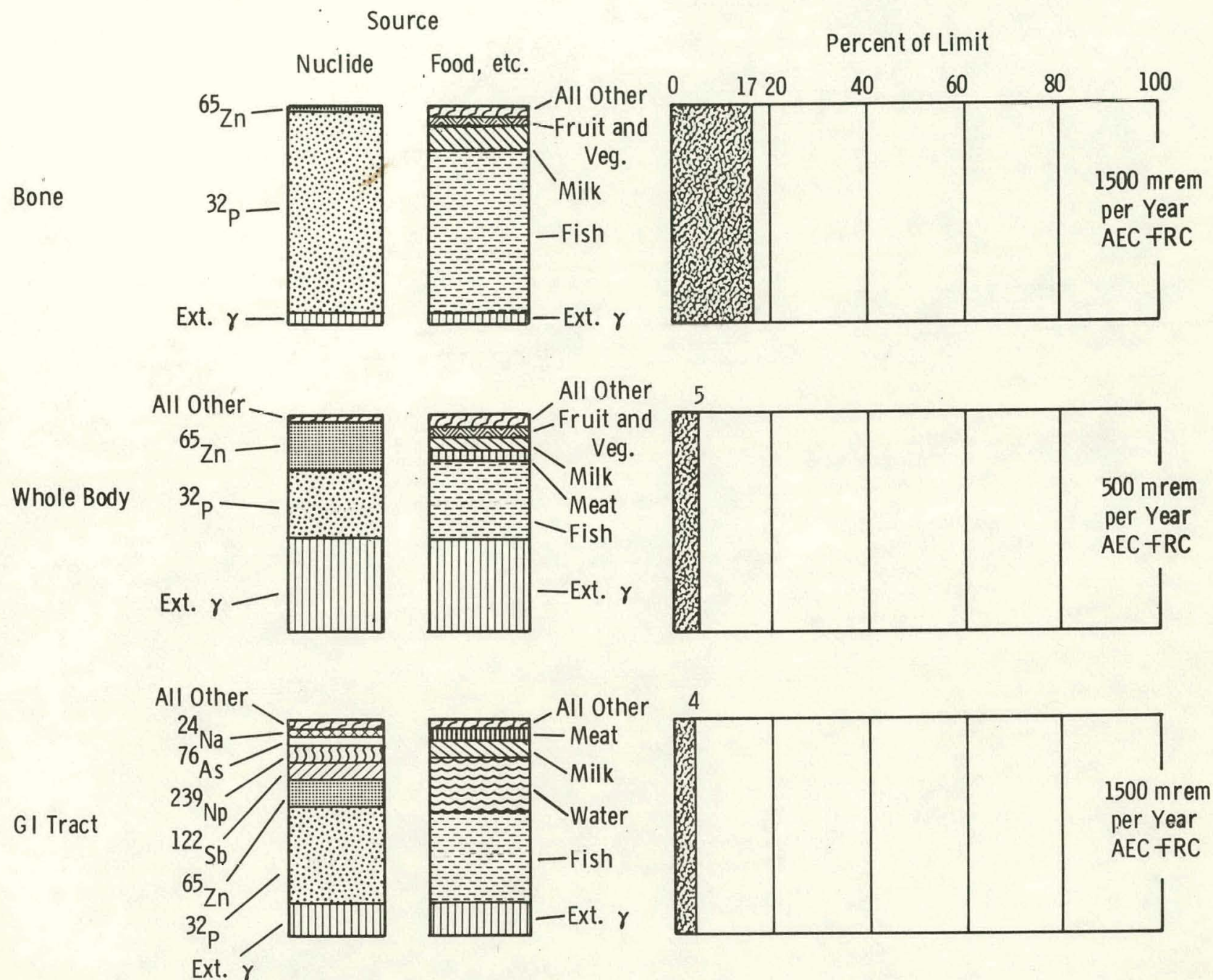

Thyroid

Ext. Y
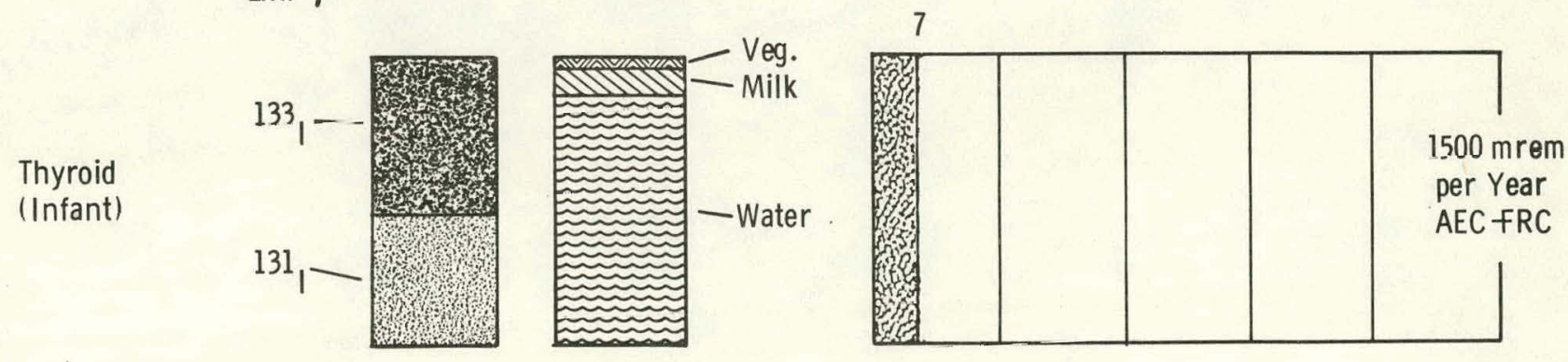


\section{ESTIMATED DOSES \\ TO THE AVERAGE ADULT RICHLAND RESIDENT-1968}

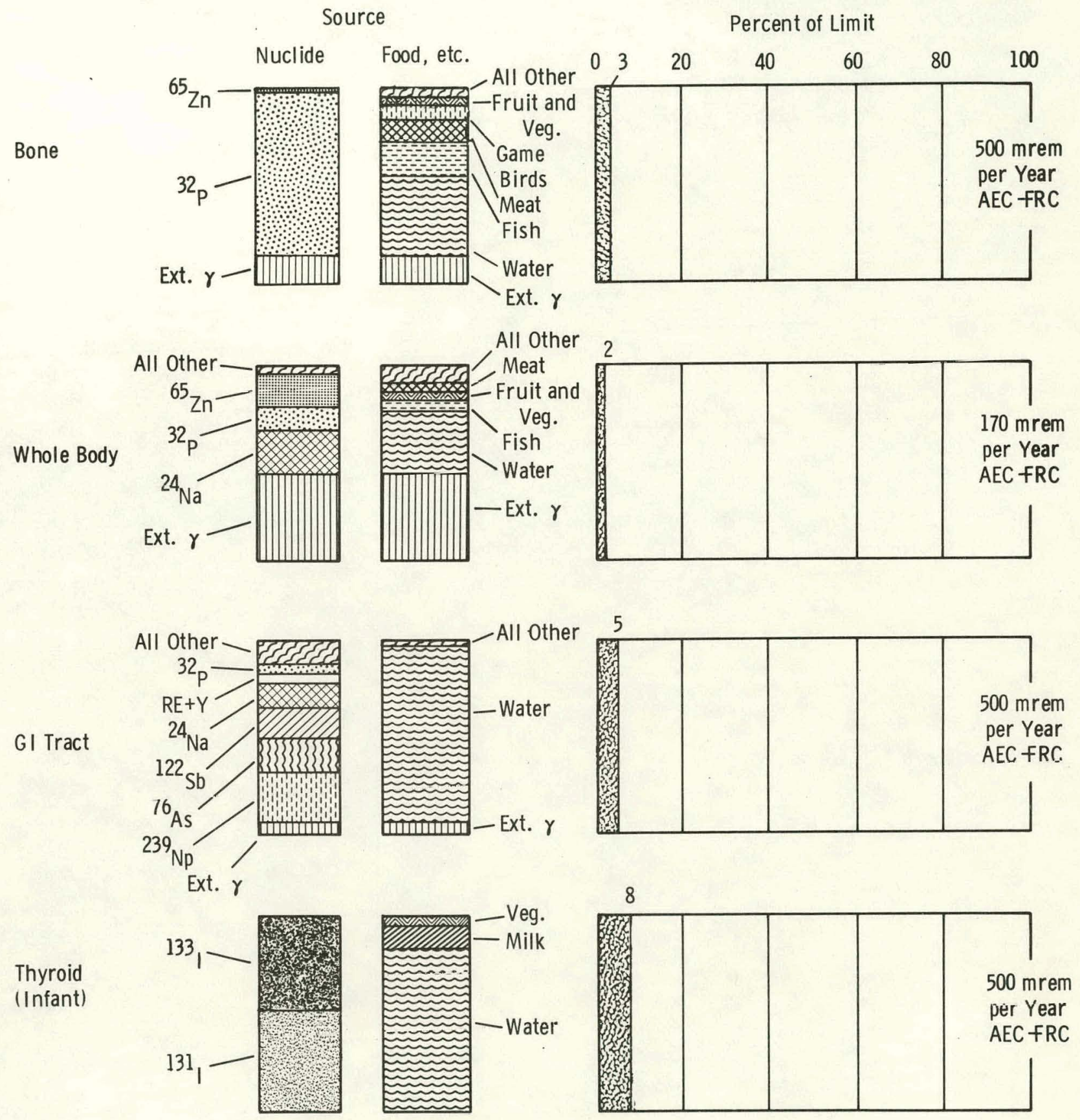


EFFECTS OF CARONIC INGESTION OF RADIONUCLIDES ON TROUT

\begin{tabular}{|c|c|c|c|c|c|}
\hline \multicolumn{2}{|c|}{$\frac{\text { Treatment }}{\mu \mathrm{C} / \mathrm{g} \text { fish/day }}$} & Mortality & $\begin{array}{c}\text { Growth } \\
\text { Depression } \\
\end{array}$ & $\begin{array}{c}\text { Gut } \\
\text { Damage }\end{array}$ & $\begin{array}{l}\text { Blood } \\
\text { Damage }\end{array}$ \\
\hline \multirow[t]{3}{*}{$32 \mathrm{P}$} & .006 & No & No & No & No \\
\hline & $: 06$ & No & Wk $\quad 17$ & No & 4 mos. \\
\hline & .6 & Yes & Wk 11 & Yes & 17 days \\
\hline \multirow[t]{3}{*}{${ }^{90} \mathrm{Sr}$} & .005 & No & No & No & No \\
\hline & .05 & No & No & No & No \\
\hline & .5 & Wk 15 & Wk 12 & Yes & Wk 15 \\
\hline \multirow[t]{4}{*}{${ }^{65} \mathrm{zn}$} & $.0 \mathrm{I}$ & No & No & No & No \\
\hline & .1 & No & No & No & No \\
\hline & 1.0 & No & No & No & No \\
\hline & 0.0 & No & No & No & Wk 10 \\
\hline
\end{tabular}




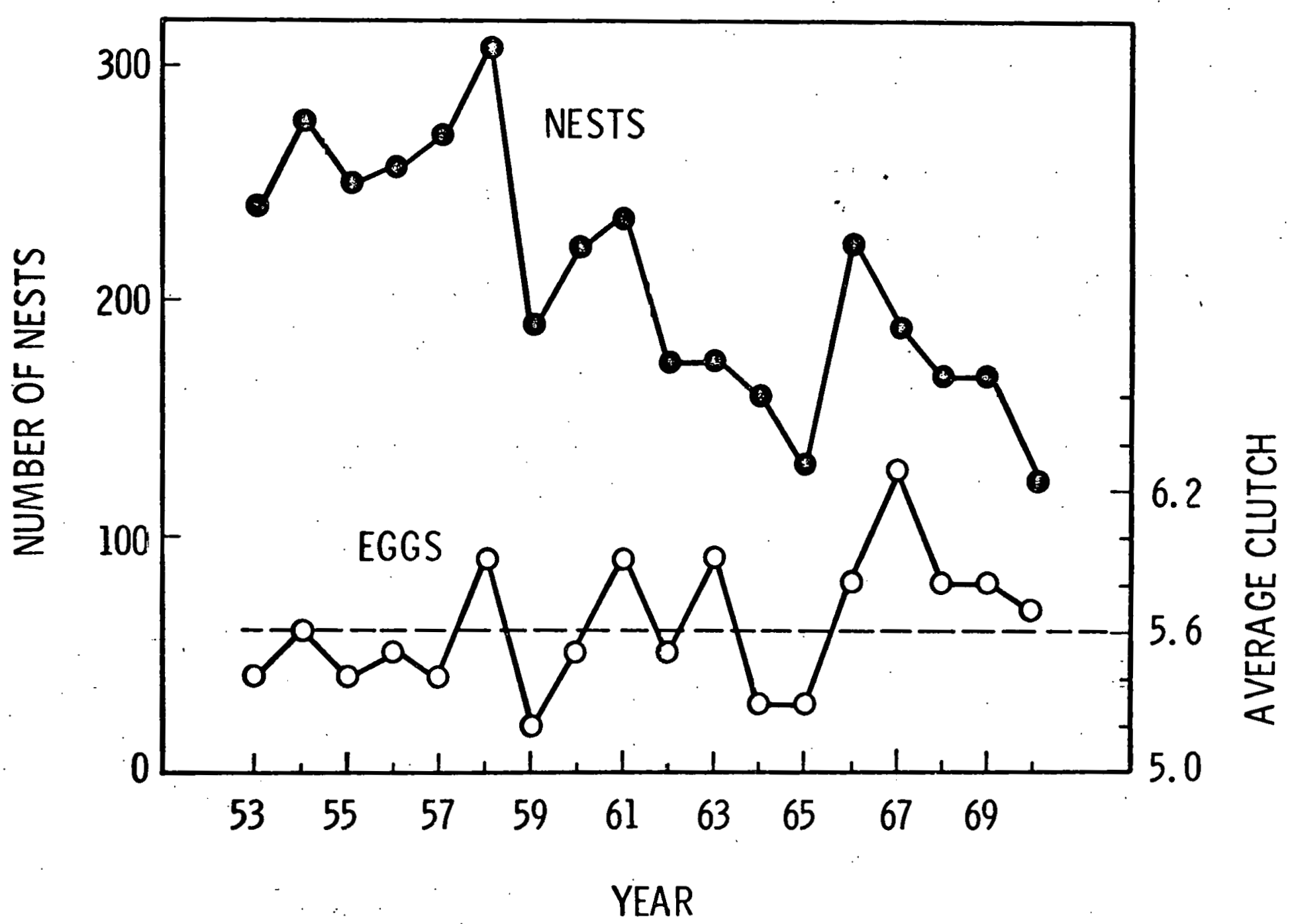

CANADA GOOSE NESTING CENSUS AT HANFORD

Figure 9 


\section{COLUMBIA RIVER SURFACE TEMPERATURE PATTERNS \\ $80,000 \mathrm{cfs}$}

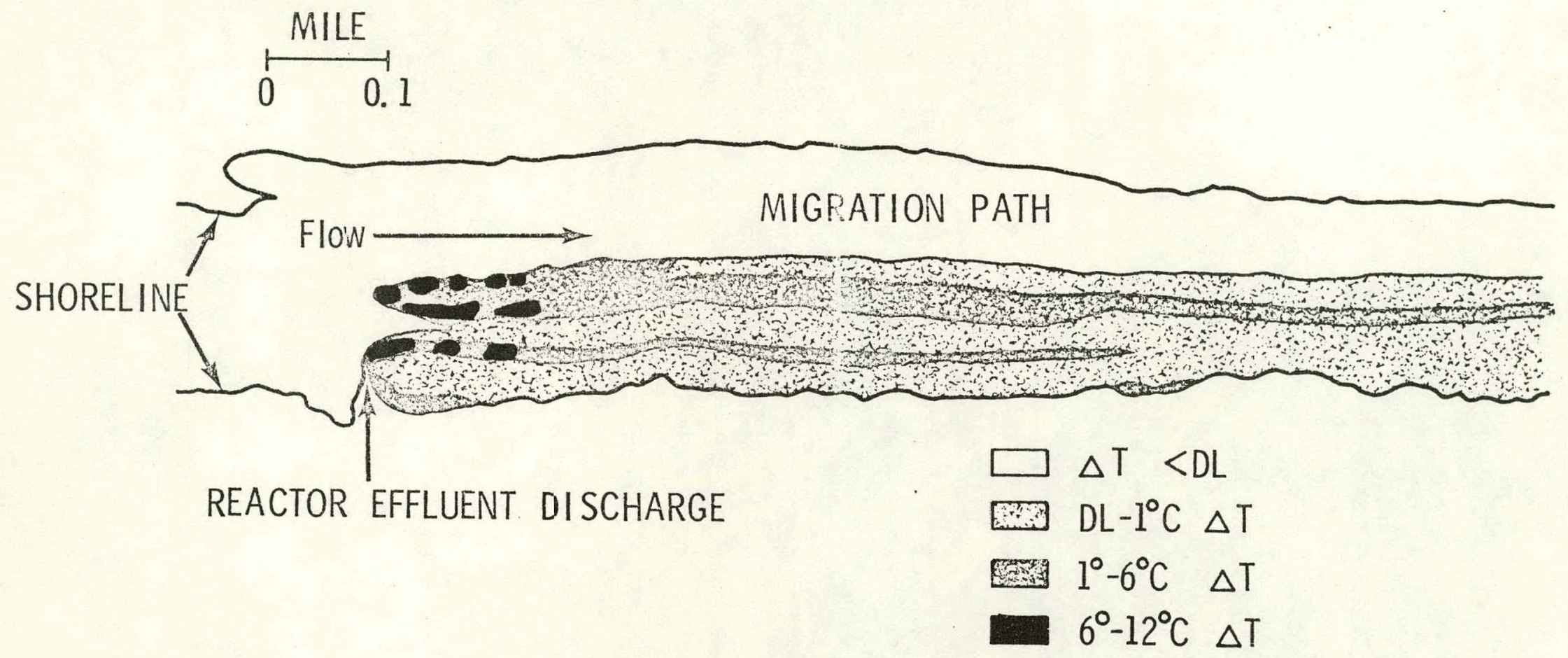




\section{COLUMBIA RIVER TEMPERATURES AT ROCK ISLAND}

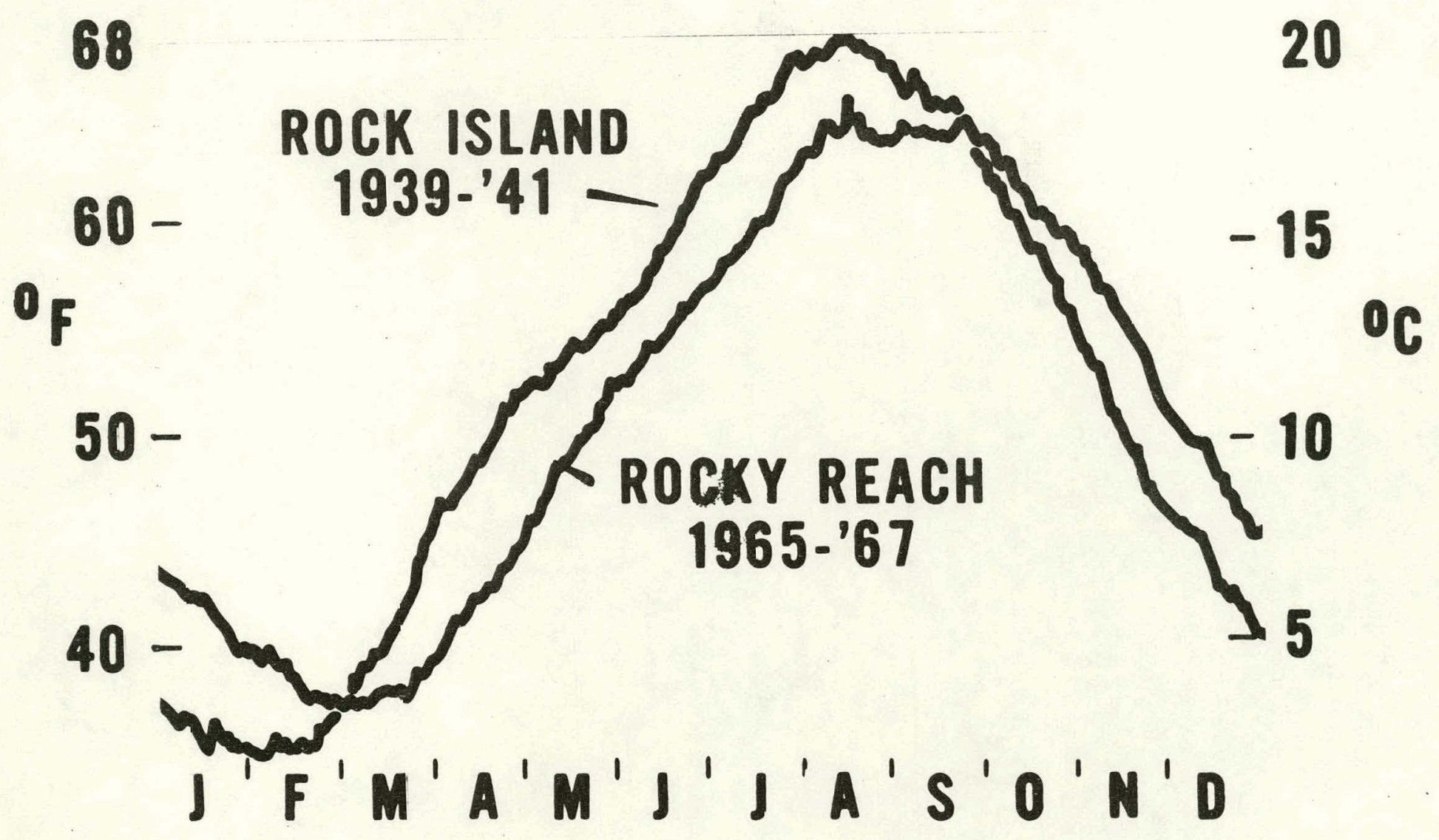


COLUMBIA RIVER TEMPERATURES AT BONNEVILLE DAM

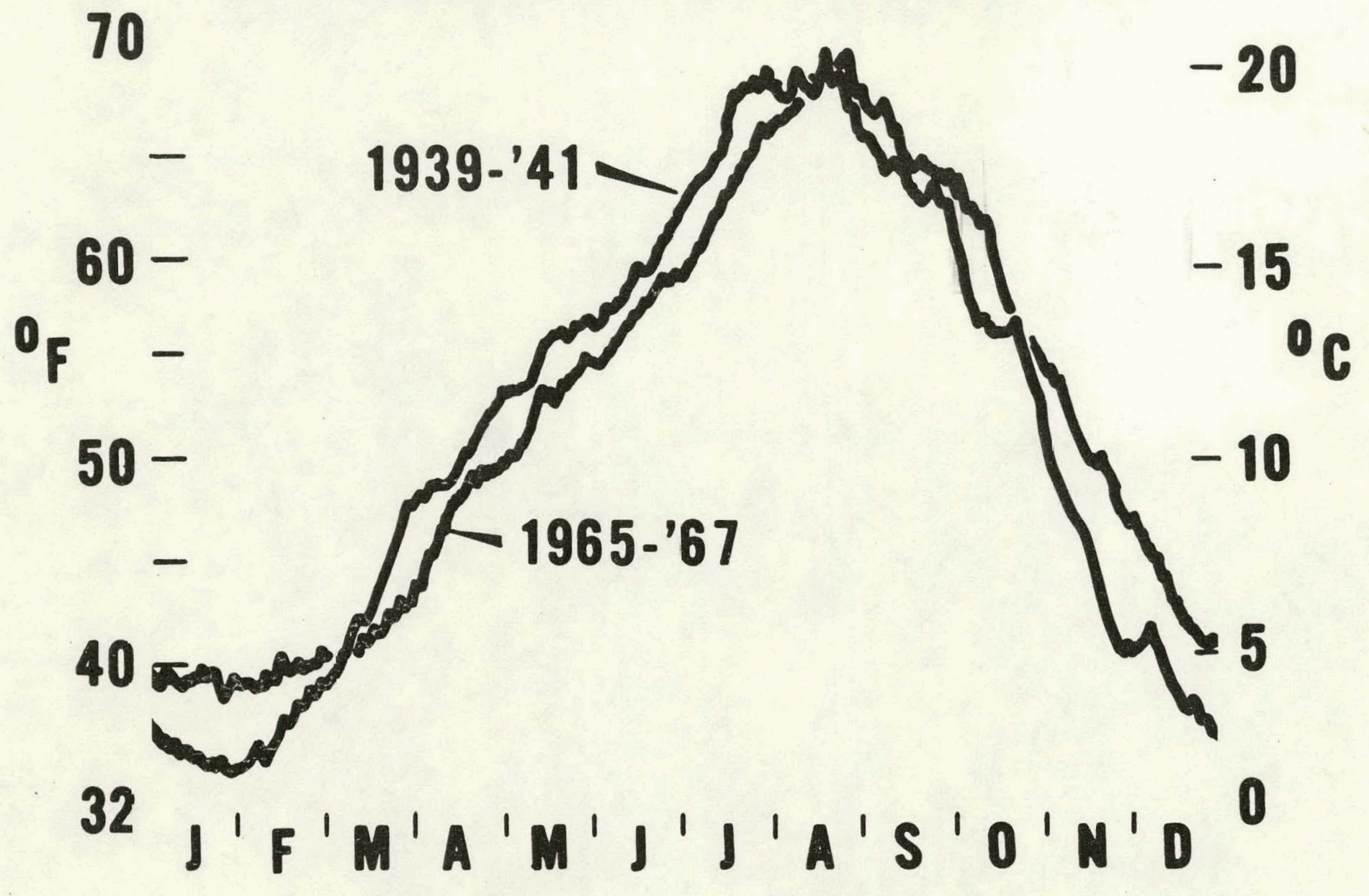




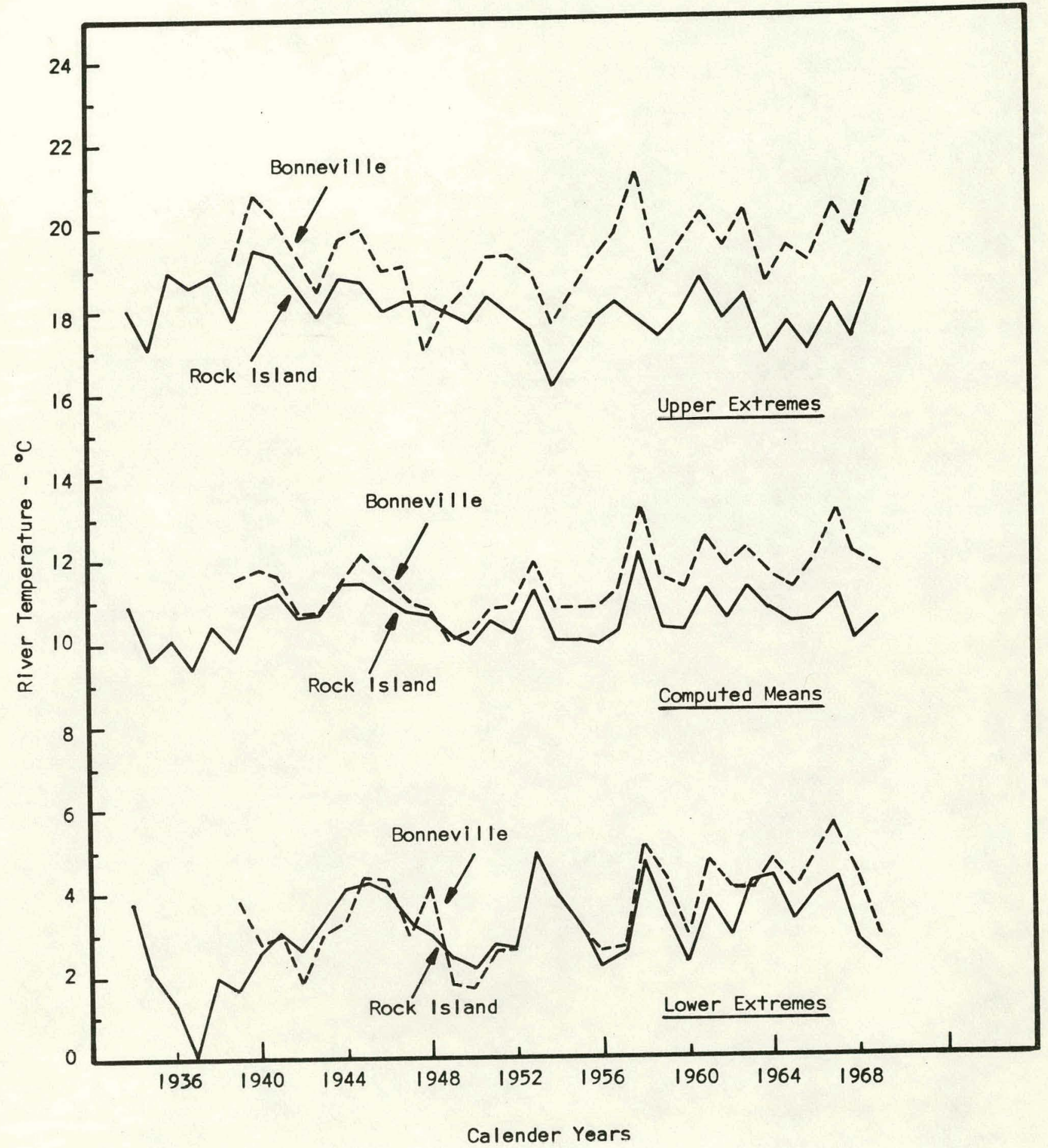

Figure 13 


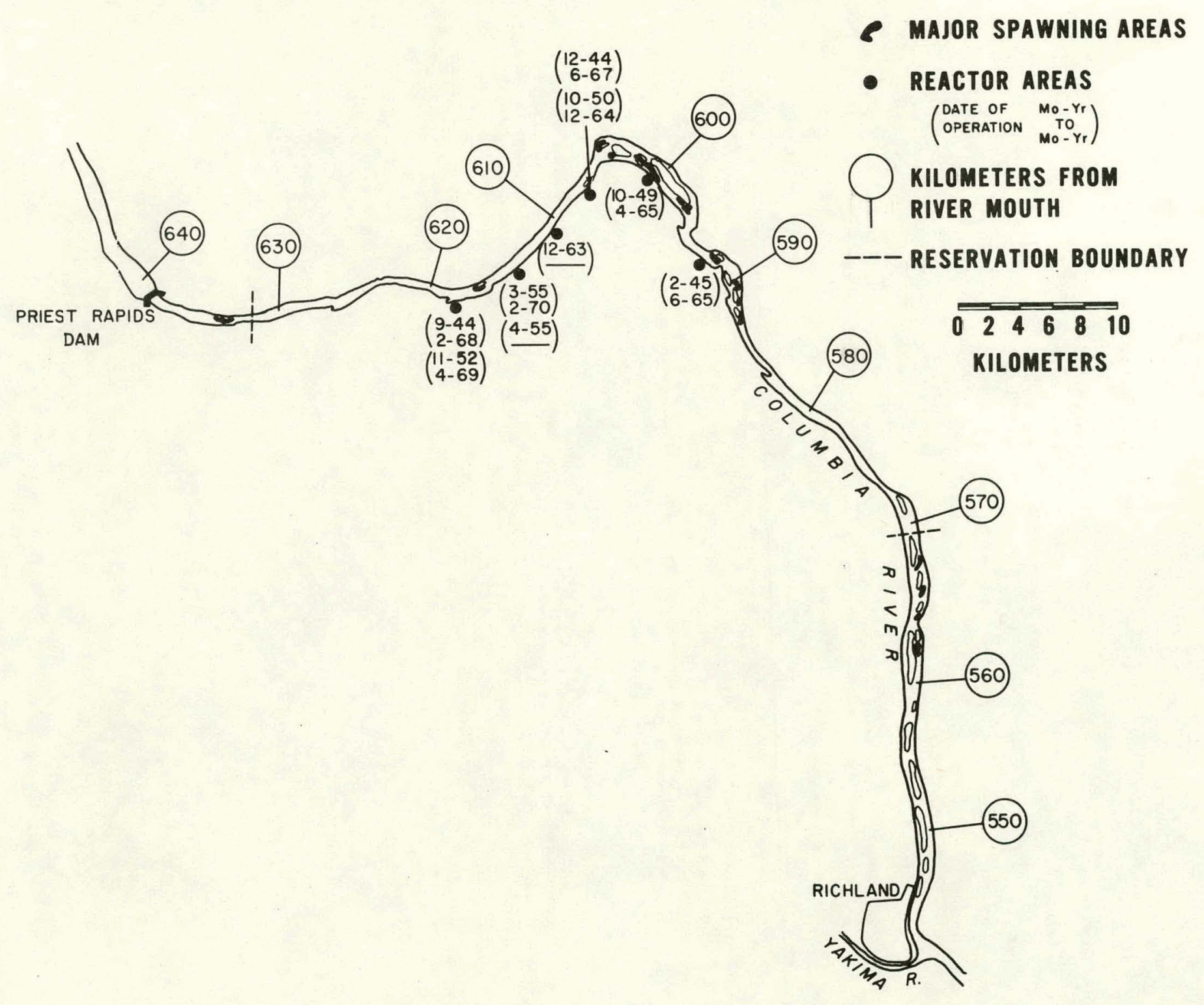

Spawning areas of chinook salmon in the Hanford area. 
SALMON SPAWNING ABOVE AND BELOW REACTORS

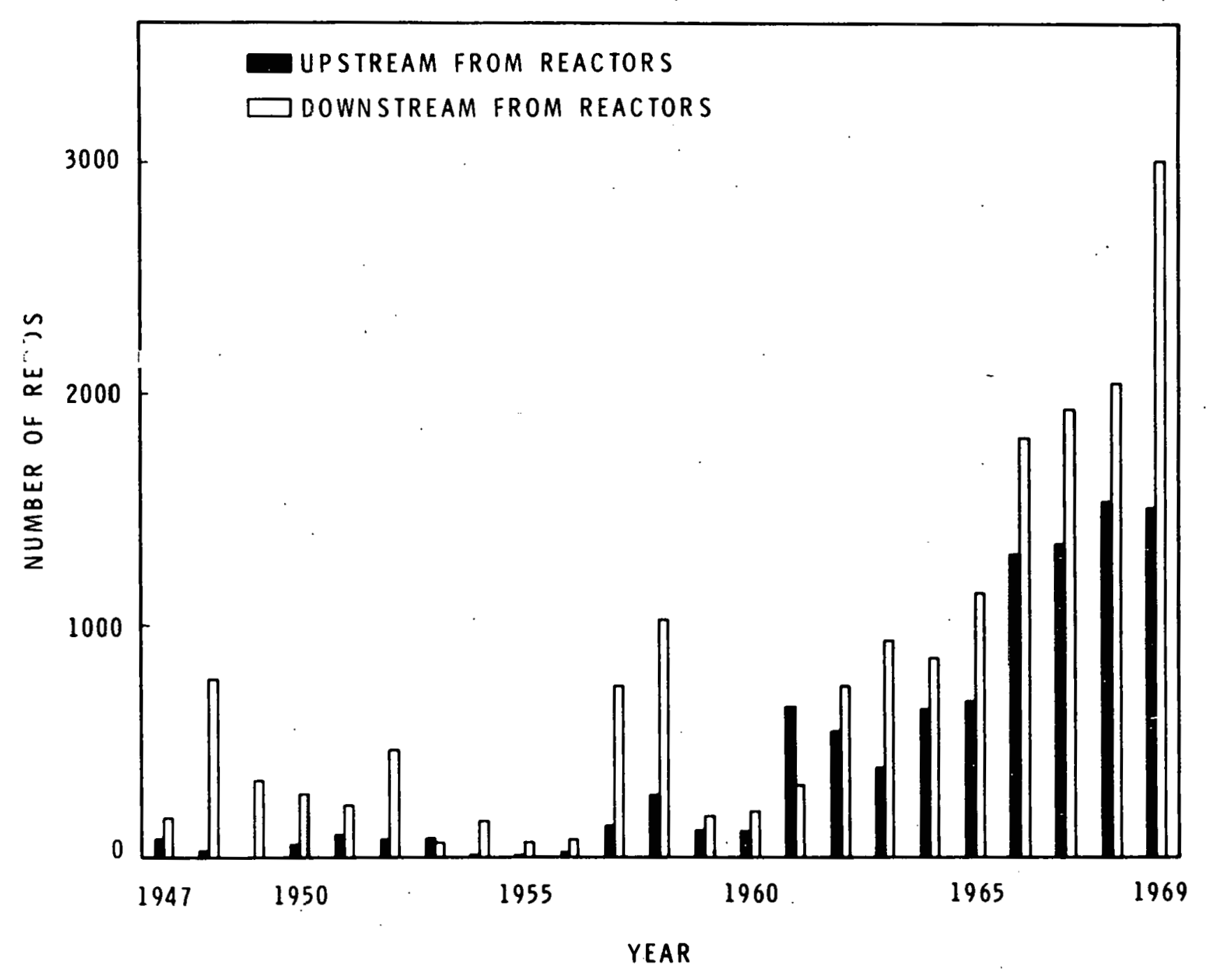

Figure 15 